\title{
TWO NEW HYPORHEIC AMPHIPODS, BOGIDIELLA (BOGIDIELLA) CYRNENSIS N. SP. AND BOGIDIELLA (MEDIGIDIELLA?) PAOLII N. SP., FROM CORSICA
}

\author{
by \\ F. HOVENKAMP, W. HOVENKAMP \& J. J. VAN DER HEIDE \\ clo Institute of Taxonomic Zoology, University of Amsterdam, \\ P.O. Box 20125, 1000 HC Amsterdam, The Netherlands
}

\section{SUMMARY}

Two new amphipod species of the family Bogidiellidae were found in the hyporheal of two small rivers on Corsica. Both new species, Bogidiella (Bogidiella) cymensis n. sp. and $B$. paolii $\mathbf{n}$. sp. (provisionally placed in the subgenus Medigidiella, but a definitive classification will have to wait till males are found), encountered at altitudes of $135 \mathrm{~m}$ and $750 \mathrm{~m}$, respectively, show more affinities with certain freshwater species of Sardinia than with marine species of the Mediterranean.

\section{RÉSUMÉ}

Deux espèces nouvelles d'Amphipodes de la famille des Bogidiellidae ont été découvertes dans l'hyporhéique de deux cours d'eaux de Corse. Les deux espèces, Bogidiella (Bogidiella) cyrnensis n. sp. et B. paolii n. sp. (provisoirement placée dans le sous-genre Medigidiella, mais dont l'attribution définitive doit attendre la découverte du sexe mâle), trouvées à des altitudes de 135 et de $750 \mathrm{~m}$ respectivement, montrent d'affinités plus étroites avec certaines formes d'eau douce de la Sardaigne, qu'avec les espèces marines de la Méditerranée.

\section{INTRODUCTION}

During a research trip on the island of Corsica, supported by the Institute of Taxonomic Zoology of the University of Amsterdam, we collected in the hyporheal of two places specimens of the amphipod family Bogidiellidae Hertzog, 1933.

Because of the sampling method (with the biophreatical pump) most specimens were damaged. In one locality only female specimens were found, all lacking uropod III. In the other locality all specimens were devoid of pereiopod VII.
The specimens clearly belong to two different species, but owing to the absence of males the subgeneric status of one of the species must remain unsettled. The discovery of these species brings the number of bogidiellid species known from Corsica to three, of which the presently described taxa are the first freshwater species. The other known Corsican species is Bogidiella (Medigidiella) chappuisi Ruffo, 1952, which lives in brackish interstitial water (Ruffo, 1954).

The type-specimens have been deposited in the amphipod collection of the Zoological Museum of the University of Amsterdam (ZMA).

\section{Bogidiella (Bogidiella) cyrnensis n. sp.} (figs. 1-3)

Material examined. - Seventeen males and five females $(1.1-1.7 \mathrm{~mm})$, from interstitia in fine gravel and silt, Corsica, Cap Corse, Commune de Patrimonio, under the bridge of road D333 across the Fium Albino, altitude $135 \mathrm{~m}$. Sampled by means of the biophreatical pump, on 7 October 1981, by F. and W. Hovenkamp and J. J. van der Heide, at $20 \mathrm{~cm}$ under the substrate surface; water temperature $19^{\circ} \mathrm{C}, \mathrm{pH} 7.1, \mathrm{Cl}^{-} 28 \mathrm{mg} / \mathrm{l}, \mathrm{Ca}^{+}+150 \mathrm{mg} /$. Associated fauna: Stenasellus sp., larval Coleoptera. A possible symbiotic ciliate (fig. 1E) was found between the pereiopods of most males.

Holotype (female $1.7 \mathrm{~mm}$ ) and 17 paratypes are dissected and mounted on microscope slides in Reyne's modification of Faure's liquid; 4 paratypes are preserved in alcohol 70\% (ZMA coll. no. Amph. 107.575).

Description. - Based on the holotype and 5 paratypes. Body length of females 1.3-2.2 mm, of males 1.1-2.2 mm. Eyes absent, body depigmented. 


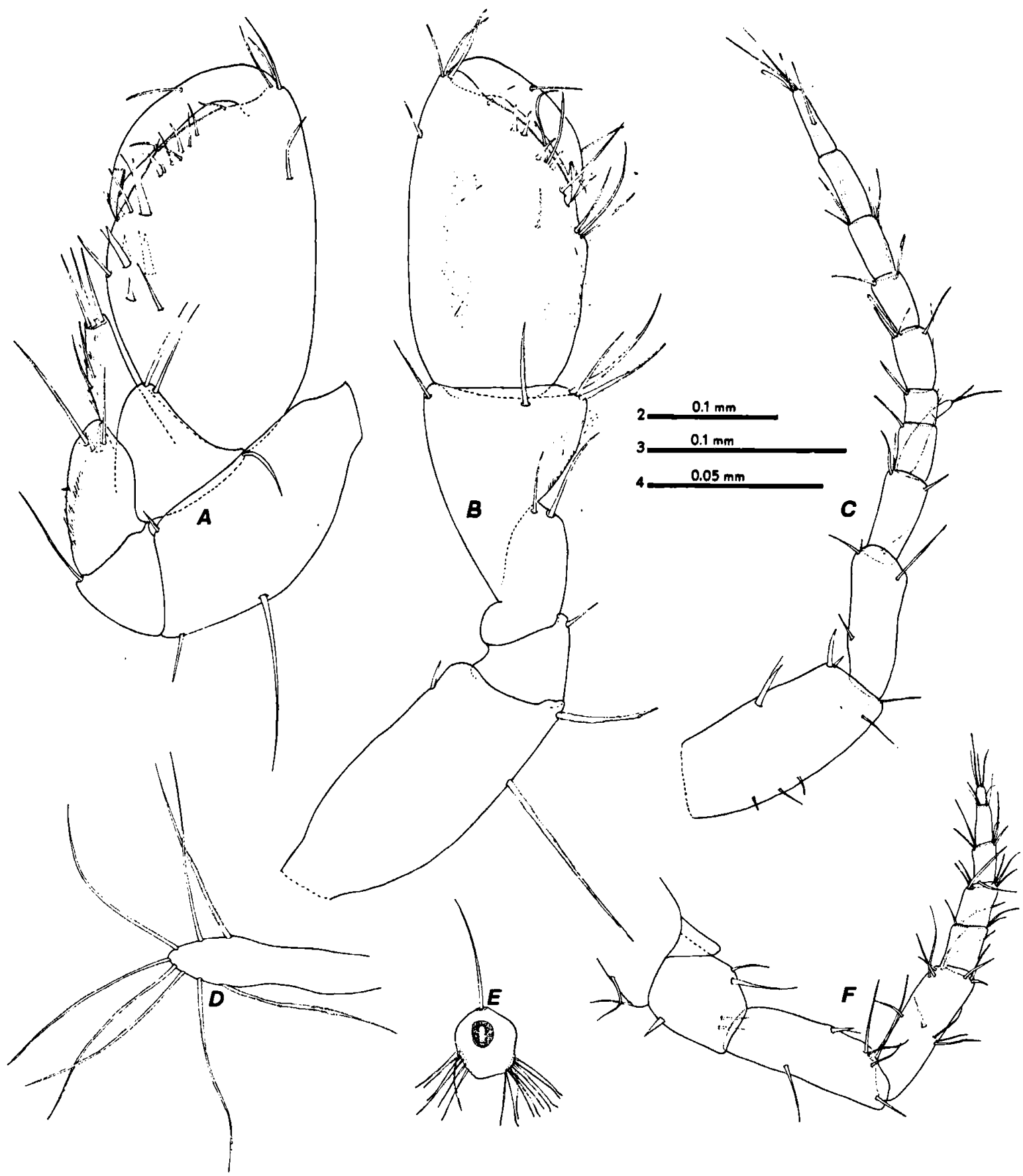

Fig. 1. Bogidiella (Bogidiella) cyrnensis n. sp.: A, gnathopod I holotype $\$ 1.7 \mathrm{~mm}$ (scale 2); B, gnathopod II holotype (2); C, antenna I holotype (2); D, oöstegite paratype $92 \mathrm{~mm}$ (3); E, ciliate found on pereiopods (4); F, antenna II holotype (2).

Pereion, pleon and coxal plates (figs. 2 E-K) inferior corner, posterior margin slightly conwithout particular characteristics. First cave, with one seta implanted at the corner. epimeral plate (fig. 3L) with rounded postero- The second epimeral plate (fig. 3M) with a 
pointed posteroinferior corner; the third (fig. $3 \mathrm{~N}$ ) with an acute one, both plates with one seta at the posterior margin.

Coxal gills (fig. 2L) on pereionites IV to VI, large, oval. Peduncle slightly longer than wide.

Secondary sexual dimorphism absent. Oöstegites (fig. 1D) present on body somites corresponding with $\mathrm{P}$ II to $\mathrm{P} \mathrm{V}$.

Antenna I (fig. 1C) about $1 / 3$ of the length of the body. Flagellum consisting of 7 articles, the second article shorter than the first and the third article. Aesthetasks on articles 3 to 7. Accessory flagellum 2-segmented, just reaching to the tip of the second article of the main flagellum, first article more than twice as long as the second.

Antenna II (fig. 1F) with flagellum of 5 articles, shorter than the peduncle, fifth article shorter than any of the other articles.

Mandible (fig. 3B): pars molaris with one small seta. First article of palp shorter than second and third article. Second article with 1 apical and 1 ventral seta. Third article with 3 long apical setae and 1 shorter subapical seta.

Maxilla I (fig. 3C): inner lobe shorter than outer lobe, with two apical setae. Large outer lobe, armed with 8 apical spines, of which 6 unidentate and 2 bidentate. Palp with elongate distal article, armed with 2 apical and 1 subapical setae.

Maxilla II (fig. 3D): both lobes of equal length, armed with 6 to 7 apical setae, inner lobe with 2 subapical cilia.

Maxilliped (fig. 3A): inner lobe with 2 robust apical spines of which 1 sometimes bidentate. Outer lobe reaching till second article of the palp, with 3 apical spines, and 3 apical and 3 medial setae. Fourth article of palp with a subapical group of cilia, dactylus with a group of cilia on the inner margin.

Labium as illustrated in fig. 3E.

Gnathopods I (fig. 1A) and II (fig. 1B) with one long seta in the middle of the posterior margin of the basis, and one seta on the posterior margin of the ischium. Merus of gnathopod I with ciliate posterior margin. Carpus of gnathopod I triangular with strong digitiform projection, armed with 3 apical setae, 2 proximal setae and numerous cilia. Palmar index of propodus of gnathopod I 0.53. Apical part of palmar margin finely serrate. Number of posterolateral spines variable, normally 1 spine and 1 seta, but sometimes more, up to 4 spines. Carpus of gnathopod II elongate triangular, with 5 long setae and a ciliate posterior margin. Palmar index of propodus of gnathopod II ca. 0.38 , propodus with a lateral group of cilia and a ciliate posterior margin. Apical part of palmar margin finely serrate.

Pereiopods III to VI (figs. 2A-D) progressively longer, all with almost circular lenticular organs. Pereiopods III and IV similar, except for a small difference in size. Lenticular organs mostly with a sinuous or partly sinuous, but sometimes smooth, interior margin; different shapes can be found within a single specimen.

Pleopods I (fig. 3G) to III identical, endopodites totally lacking. Peduncle with 2 retinacula. Each article of exopodite armed with 2 sparsely plumose setae.

Uropod I (fig. $3 \mathrm{H}$ ) with equal rami, shorter than peduncle. Peduncle with 2 subapical spines. Both rami with 4 to 5 apical spines, one of which of more than half the length of the ramus.

Uropod II (fig. 3I) with rami of equal length, shorter than the peduncle. Peduncle armed with 2 subapical spines. Both rami armed with 4 to 5 apical spines, one of which longer than half the length of the ramus.

Uropod III (figs. 3J-K) long, with equal rami or outer ramus slightly shorter. Peduncle armed with 2 spines. Inner ramus armed with a lateral group of 2 or 3 spines and with 5 or 6 apical spines. One apical spine on both rami is more than half the length of the ramus. The number of spines on the rami could be dependent on size, but only three uropods III were available.

Telson (fig. 3F) wider than long, with a slightly concave posterior margin, each side armed with 1 apical spine, about as long as the telson, and 2 small subapical setae.

Derivatio nominis. - The specific name cyrnensis refers to Cyrnos (Kúpvos) which is the classical Greek name for Corsica. 


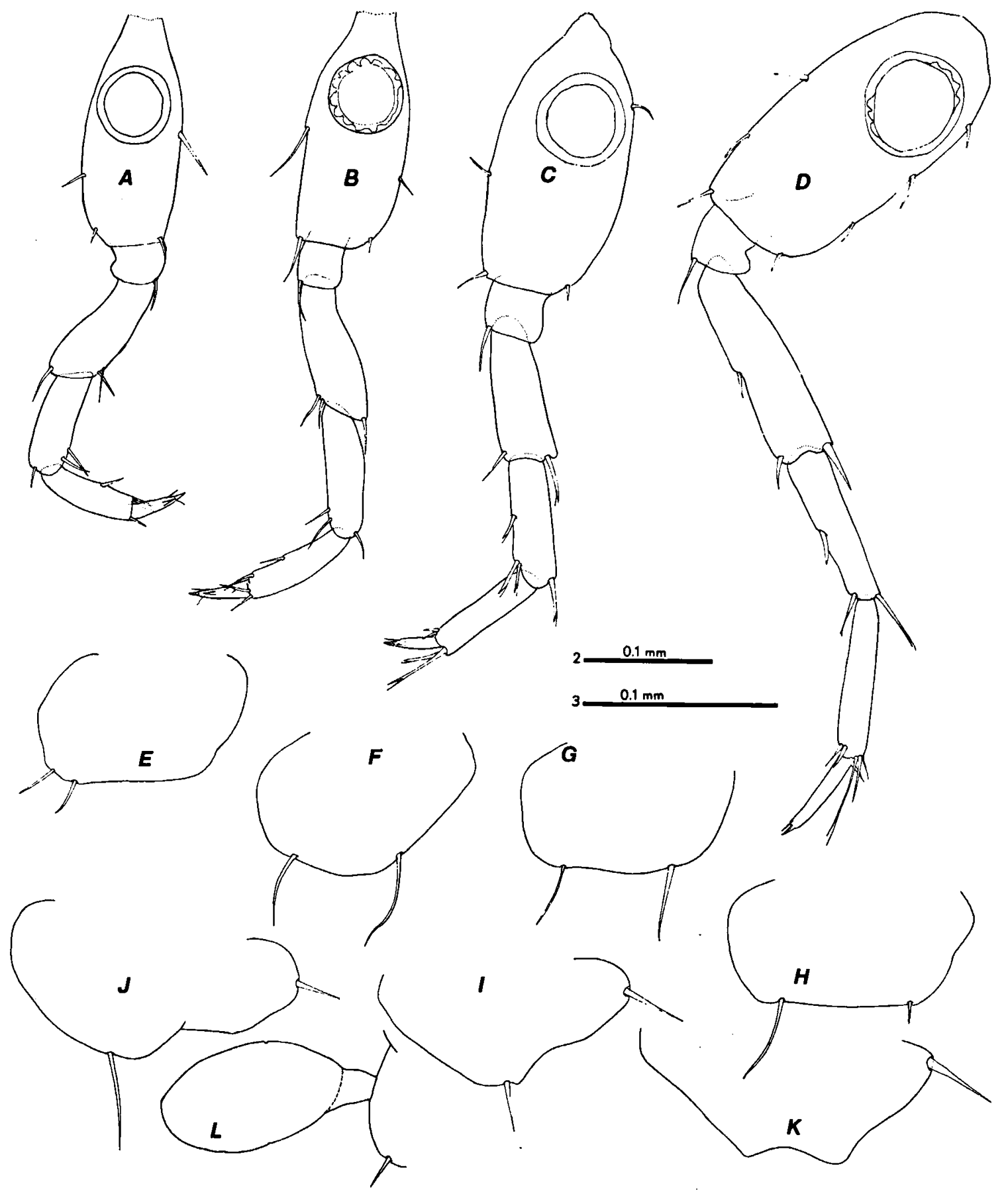

Fig. 2. Bogidiella (Bogidiella) cyrnensis n. sp.: A-C, pereiopods III-V holotype $\$ 1.7 \mathrm{~mm}$ (scale 2); D, pereiopod VI paratype (size and sex unknown) (2); E-K, coxal plates I-VII holotype (3); L, coxal gill holotype (3).

Remarks and affinities. $-B$. (B.) cyrnensis n. sp. belongs to the subgenus Bogidiella Hertzog, 1933, and is very close to $B$. $(B)$. ichnusae ichnusae Ruffo \& Vigna-Taglianti, 1975, B. (B.) ichnusae africana G. S. Karaman \& Pesce, 1980, B. (B.) albertimagni Hertzog, 1933, and B. (B.) glacialis S. L. Karaman, 1959.

From $B$. (B.) ichnusae ichnusae it differs by the 


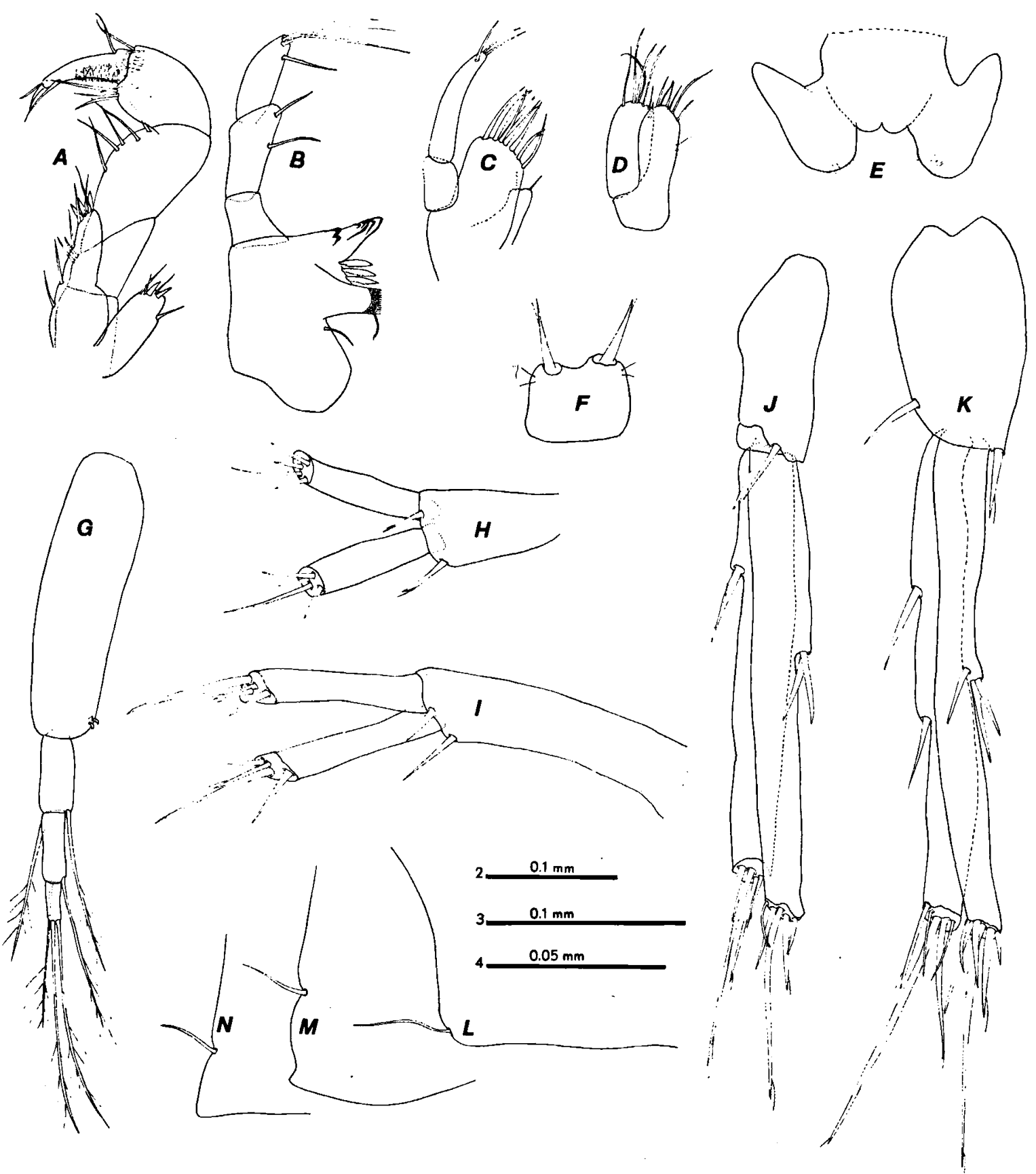

Fig. 3. Bogidiella (Bogidiella) cymensis n. sp.: A, maxilliped paratype $\sigma^{\circ} 1.3 \mathrm{~mm}$ (scale 3); B, mandible paratype $९ 1.7 \mathrm{~mm}$ (3); C, maxilla I paratype Oo (size unknown) (4); D, maxilla II paratype $\$ 1.7 \mathrm{~mm}(3)$; E, labium holotype (4); F, telson paratype ơ $1.3 \mathrm{~mm}(4)$; G, pleopod I holotype (2); H-J, uropods I-III paratype $\sigma$ $1.3 \mathrm{~mm}(3) ; \mathrm{K}$, uropod III paratype ơ $1.4 \mathrm{~mm}(3)$; L-N, epimeral plates I-III paratype $\$ 1.7 \mathrm{~mm}(3)$.

number of articles of the main flagellum of antenna I and of the accessory flagellum (7 and 2 instead of 8 and 3 articles). Other differences are the small size, the presence of setae on the molar and on the epimeral plates, the shape of the epimeral plates, the shape of the propodus 
of the gnathopods, the lack of a basofacial spine on the peduncle of the first uropod, the small inner lobe of maxilla I and the presence of a spine on the propodus of pereiopods III and IV.

With $B$. (B.) ichnusae africana it shares the number of articles of the main flagellum of antenna $I$ and the presence of setae on the epimeral plates, but in addition to the differences mentioned above for $B$. (B.) ichnusae ichnusae, it differs by the number of lateral teeth on the spines of maxilla I ( 1 instead of 3 ) and the more distinctly serrated palmar margin of the propodus of gnathopods I and II.

From $B$. (B.) albertimagni it differs by the more ovoid (less elongate) shape of the basal segments of the pereiopods, and the smaller and more rounded lenticular organs. Other differences are the presence of a long seta on the basal segment of the gnathopods, the lower number of articles of the accessory flagellum and the presence of a seta on the epimeral plates.

From B. glacialis, of which the subgeneric status is uncertain (Stock, 1981), it differs by the lower number of articles of antenna I ( 7 instead of 8), the lower number of setae on the second article of the mandibular palp ( 2 instead of 1 ) and on the inner lobe of maxilla I (2 instead of 3), the shape of the basal article of the pereiopods, the distinctness of the lenticular organs, and the less deep distal notch of the telson.

Bogidiella (Medigidiella?) paolii n. sp. (figs. 4-6)

Material examined. - Ten females, from interstitia in fine sand, Corsica (northwestern part), near the bridge of the road D 963 over the Melaja, a small affluent of the river Tartagine, altitude $750 \mathrm{~m}$. Sampled by means of the biophreatical pump, on 1 October 1981, by F. and W. Hovenkamp and J. J. van der Heide, at $20 \mathrm{~cm}$ under the substrate surface, water temperature $12^{\circ} \mathrm{C}$. Associated fauna: Niphargus sp., larval Plecoptera.

Holotype (female $3 \mathrm{~mm}$ ) and 7 paratypes dissected and mounted on microscope slides in Reyne's modification of Faure's liquid. Two paratypes are preserved in alcohol 70\% (ZMA coll. no. Amph. 107.574).
Description. - Based on the holotype and 5 paratypes. Body length 2.4 to $3.0 \mathrm{~mm}$. Eyes absent, body depigmented.

Pereion, pleon and coxal plates (figs. 6A-G) without particular characteristics.

First epimeral plate (fig. $6 \mathrm{~N}$ ) with rounded posteroinferior corner, second plate (fig. 6O) with slightly acute posteroinferior corner, third plate (fig. 6P) with fairly rounded posteroinferior corner. Posterior margin of second and third epimeral plates convex, all epimeral plates bearing one seta on the posterior margin.

Coxal gills (fig. 6M) on pereionites IV to VI, large, oval. Peduncle nearly as long as wide.

Oöstegites (fig. 6K) present on body somites corresponding with $\mathrm{P}$ II to $\mathrm{P}$ V.

Antenna I (fig. 4A) about $1 / 3$ of body length. Flagellum consisting of 8 articles, articles 1 and 2 shorter than the other articles. Aesthetasks on articles 3 to 8 . Accessory flagellum 2-segmented, nearly reaching to the third article of the main flagellum.

Antenna II (fig. 4B) with flagellum of 5 articles, shorter than the peduncle. Excretory cone reaching to the middle of the third article.

Mandible (fig. 4F): second article of the palp with 1 apical and 1 ventral seta. Third article with 2 apical and 2 subapical setae.

Maxilla I (fig. 4C): inner lobe with 2 apical setae, outer lobe bearing 7 spines of which 5 unidentate and 2 bidentate. Palp with elongate distal article, bearing 2 apical and 1 subapical setae. Maxilla II (fig. 4I): inner lobe slightly shorter than outer lobe. Inner lobe armed with 6 apical setae, of which 1 plumose. Cilia are implanted on the inner margin and subapical part of the inner lobe. Outer lobe armed with 9 apical setae, and with 4 cilia on the outer margin.

Maxilliped (fig. 4H) with small inner and outer lobes. Inner lobe armed with 2 robust apical bidentate spines, 3 apical and 2 subapical setae. Outer lobe armed with 3 apical spines, 2 (occasionally 3 ) apical setae and 2 setae on the inner margin. Only in the holotype the third article of the palp bears a distolateral seta. 


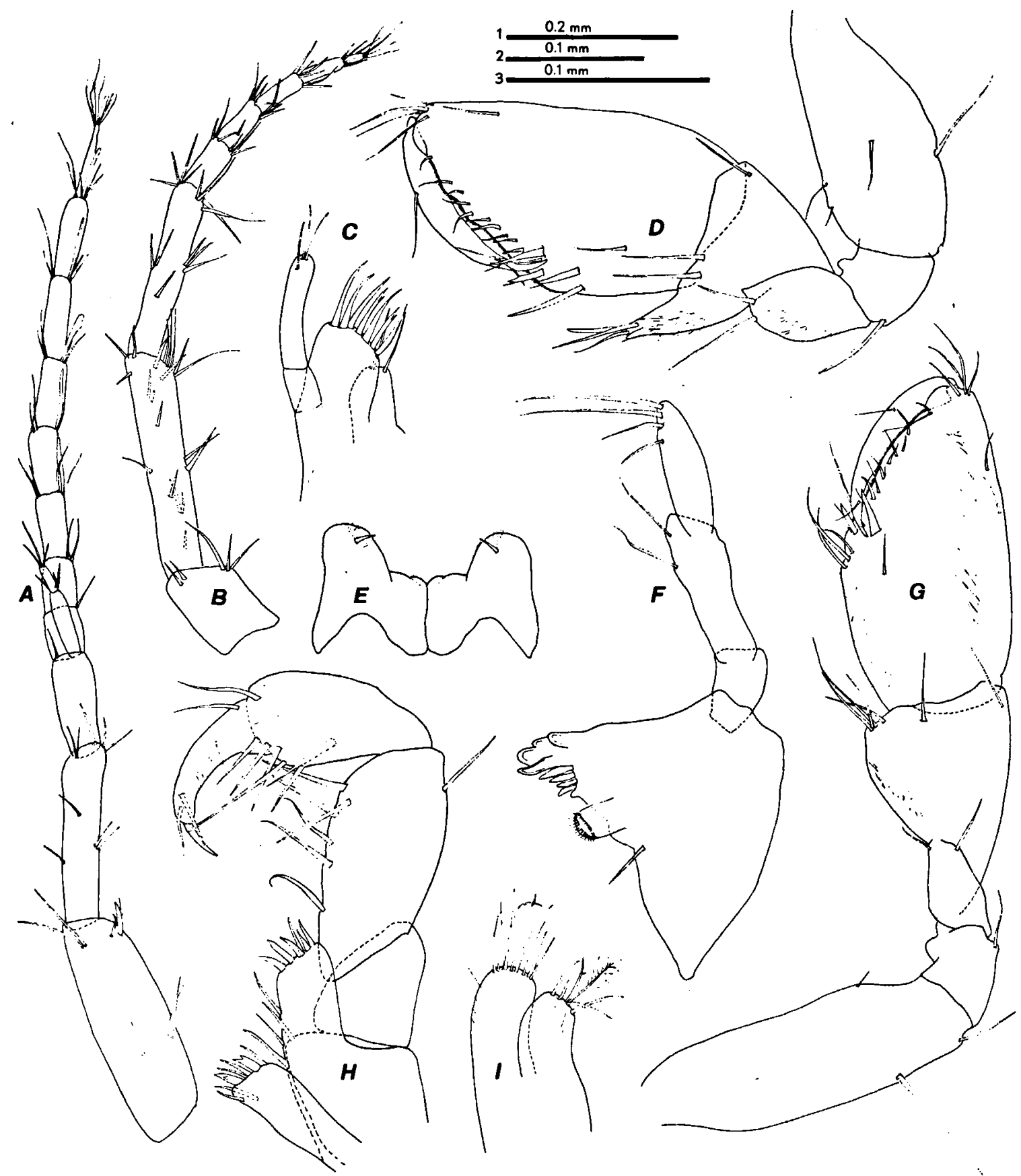

Fig. 4. Bogidiella (Medigidiella?) paolii n. sp., holotype $3.0 \mathrm{~mm}$ : A, antenna I (scale 1); B, antenna II (1); C, maxilla I (3); D, gnathopod I (2); E, labium (3); F, mandible (3); G, gnathopod II (2); H, maxilliped (3); I, maxilla II (3).

Labium (fig. 4E) with groups of cilia on inner and outer lobes. Outer lobes armed with 1 small spine.

Gnathopod I (fig. 4D): basis with a mediolateral seta. Merus with a group of cilia on the posterior margin and 2 setae. Carpus with strong digitiform projection bearing 3 long setae. Propodus with a palmar index of 0.46 , palmar margin finely ciliate.

Gnathopod II (fig. 4G): carpus with a group 


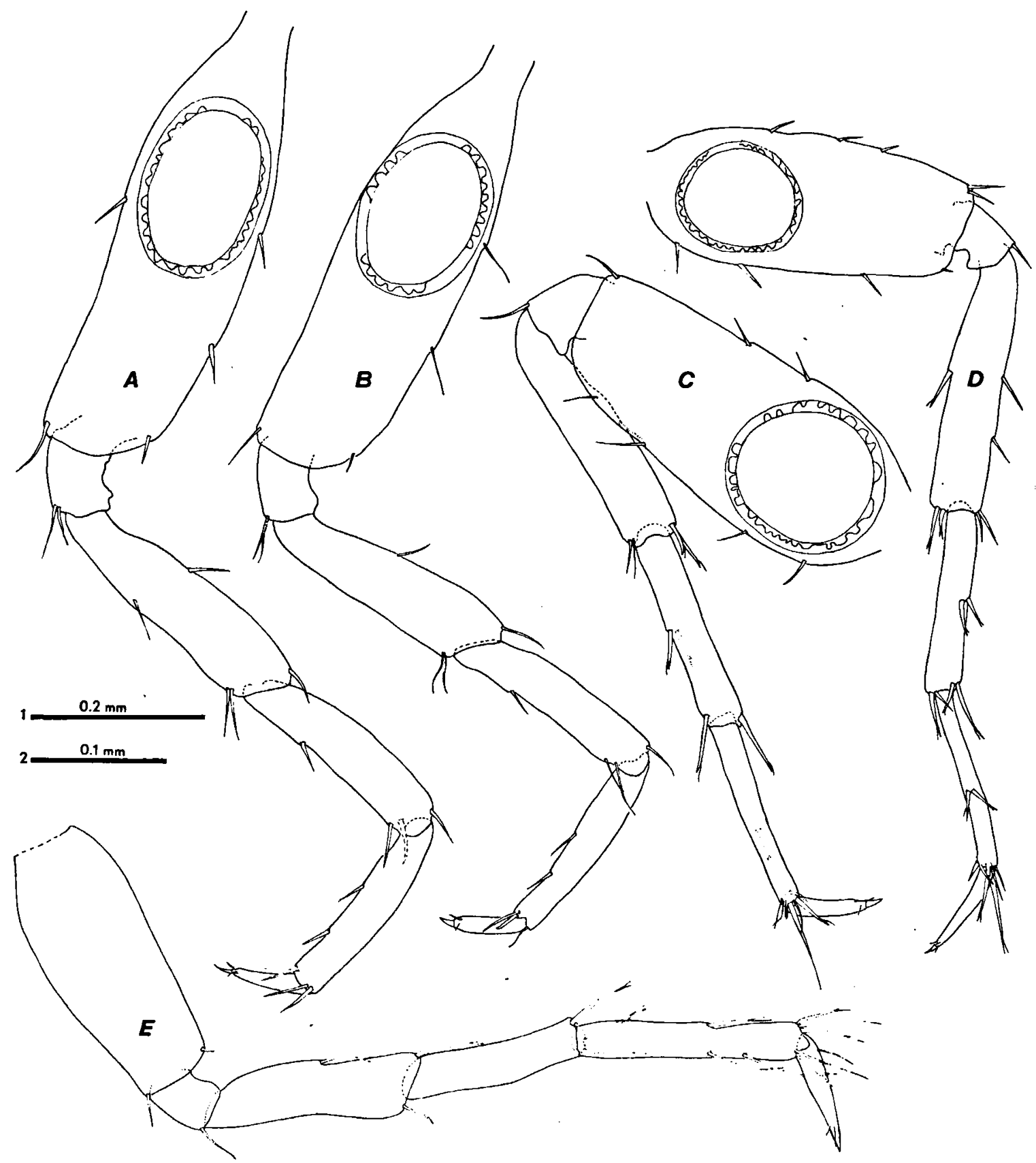

Fig. 5. Bogidiella (Medigidiella?) paolii n. sp.: A-B, pereiopods III-IV holotype $3.0 \mathrm{~mm}$ (scale 2); C, pereiopod V paratype $2.4 \mathrm{~mm}$ (2); D, pereiopod VI paratype $2.7 \mathrm{~mm}$ (1); E, pereiopod VII paratype (size unknown) (1).

of cilia on posterior margin, and 4 setae on posterodistal corner. Propodus with a palmar index of 0.44 , bearing a lateral group of cilia and a group of cilia on the posterior margin. Palmar margin set with short cilia.
Pereiopods III and IV (figs. 5A-B) nearly. similar, equal in size. Pereiopods III to VI (figs. 5A-D) with oval to circular lenticular organ, with a partly sinuous inner margin. Pereiopod VII (fig. 5E) without lenticular organ. 
Pleopods I to III (fig. 6J) identical, ramus only slightly shorter than peduncle, each article with 2 plumose setae.

Uropod I (fig. 6I) with outer ramus slightly shorter than inner ramus. Peduncle with 2 subapical spines and 1 basofacial spine, inner ramus with 5 apical spines, outer ramus with 4 apical spines, on both rami 1 spine more than half the length of the ramus.

Uropod II (fig. 6H) with outer ramus shorter than inner ramus. Peduncle armed with 2 subapical spines, inner ramus with 5 apical spines, outer ramus with 4 , sometimes 3 , apical spines, on both rami at least 1 spine more than

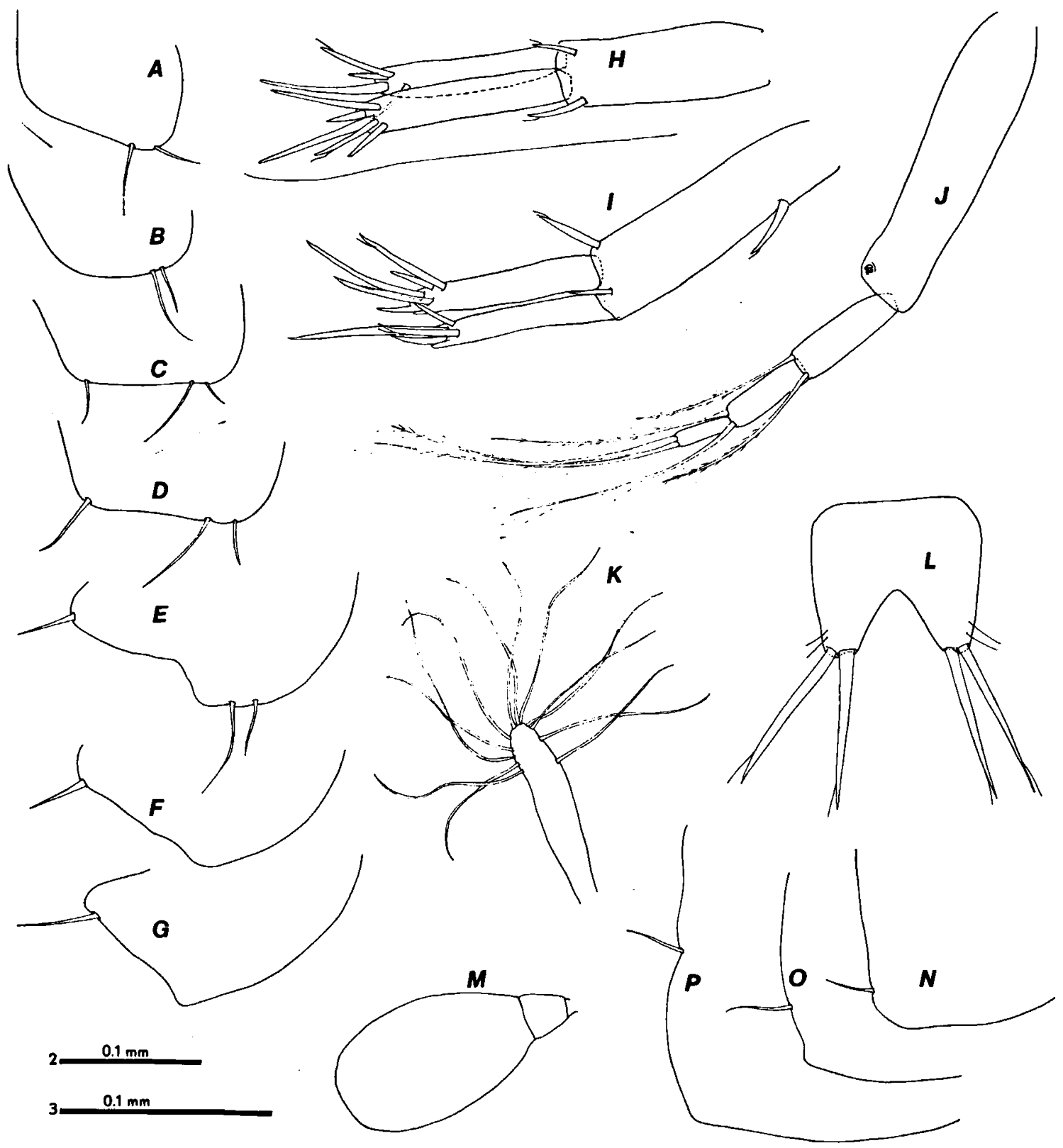

Fig. 6. Bogidiella (Medigidiella?) paolii n. sp.: A-G, coxal plates I to VII paratype $2.5 \mathrm{~mm}$ (scale 2); H, uropod II holotype (2); I, uropod I paratype $2.4 \mathrm{~mm}$ (2); J, pleopod III paratype $2.8 \mathrm{~mm}$ (2); K, oöstegite paratype $2.7 \mathrm{~mm}$ (2); L, telson holotype (3); M, coxal gill holotype (2); N-P, epimeral plates I, II and III paratype $2.5 \mathrm{~mm}$ (2). 
half the length of the ramus.

Uropod III lacking in all specimens.

Telson (fig. 6L) wider than long, with a deep distal notch. Each lobe armed with 2 apical spines, longer than the telson.

Derivatio nominis. - The name paolii refers to Pascal Paoli (1725-1807), founder of the independent state of Corsica and still honoured on Corsica as "Père de la Patrie". In 1756 he founded the University of Corte which was reopened as the "Université Pascal Paoli" during our collecting trip.

Remarks and affinities. - Bogidiella (Medigidiella?) paolii $\mathrm{n}$. sp. is compared with $B$. (M.) vandeli Coineau, 1968, B. (M.) aprutina Pesce, 1980, B. (M.) silverii Pesce, 1981 and $B$. (M.) chappuisi Ruffo, 1952. The new species looks rather close to $B$. $(M$.$) vandeli and B$. (M.) aprutina. The affinities with $B$. (M.) silverii and $B$. (M.) chappuisi are less pronounced.

The systematic relationships with other species remain unsettled till male specimens are found, but the overall resemblance to $B$. $(M$. vandeli from Sardinia has made us decide to classify the new species provisionally in the subgenus Medigidiella.

The new species differs from $B$. $(M$.$) vandeli$ in the following characteristics: the lower number of spines on the propodus of pereiopod VII, the difference in chaetotaxy of pereiopods VI and VII (but only very few pereiopods VI and VII were present), the lack of a spine on the propodus of gnathopod I (however, this character is known to be variable in at least some species, viz., in $B$. (Stygogidiella) bredini Shoemaker, 1959, and B. (B.) cyrnensis n. sp.), the more elongate ramus of the pleopods, the presence of a finely ciliate apical part of the palmar margin of gnathopods I and II, the number of lateral teeth on the spines on the outer lobe of maxilla I, the presence of 2 setae on the second article of the mandibular palp, and the number of articles of the main flagellum of antenna I.

Some remarkable similarities to $B$. (M.) vandeli are: the absence of a lenticular organ on pereiopod VII, the presence of a mediolateral seta on the basal article of gnathopod I, the deeply notched telson, and the short dactylus on all pereiopods.

Some differences with $B$. (M.) aprutina are: the lower number of spines on the apical margin of the propodus of gnathopods I and II, the lower number of articles of the accessory flagellum, the short dactylus of each pereiopod, the presence of only one basofacial spine on the peduncle of uropod I, the number of lateral teeth on the spines on the outer lobe of maxilla I, and the more elongate ramus of the pleopods.

Important differences with $B$. (M.) silverii are: the lower number of articles of the accessory and main flagellum of antenna $I$, the shape of the telson, the absence of an endopodite on the pleopods, and the lower number of spines of the peduncle of uropods I and II.

From $B$. (M.) chappuisi it differs by the shape of the lenticular organs and the telson, the lower number of articles of the accessory flagellum, and the greater number of apical spines on the inner and outer rami of uropods I and II.

The fact that $B$. (M.) paolii $\mathrm{n}$. sp. as well as $B$. (B.) cyrnensis $\mathrm{n}$. $\mathrm{sp}$. are more similar to the freshwater species of Sardinia and the European mainland than to the marine and littoral species of the Mediterranean, including Corsica, supports the theory that the differentiation of the species in the Mediterranean region may have been influenced by recent catastrophical events, as the salinity crisis in the Miocene (Stock, 1980, 1981).

\section{REFERENCES}

Coineau, N., 1968. Contribution à l'étude de la faune interstitielle - Isopodes et Amphipodes. Mém. Mus. natn. Hist. nat. Paris, (N.S.) (A, Zool.) 55 (3): 145-216.

Hertzog, L., 1933. Bogidiella albertimagni sp. nov., ein neuer Grundwasseramphipode aus der Rheinebene bei Strassburg. Zool. Anz., 102 (9/10): 225-227.

Karaman, G. S. G. L. Pesce, 1980. On three subterranean amphipods from North Africa (Amphipoda: Gammaridae). Bull. zool. Mus. Univ. Amsterdam, 7 (20): 197-207. 
Pesce, G. L., 1980. Bogidiella aprutina n. sp., a new subterranean amphipod from phreatic waters of central Italy. Crustaceana, 38 (2): 139-144.

- , 1981. A new phreatic Bogidiella from subterranean waters of Sardinia (Crustacea Amphipoda, Gammaridae). Revue suisse Zool., 88 (1): 157-162.

Rufro, S., 1954. Bogidiella chappuisi Ruffo - nouvel Amphipode phréatobie de la faune française. Archs. Zool. exp. gén., 91 (1): 145-152.

Ruffo, S. A. Vigna-Taglianti, 1975. Una nueva Bogidiella della Sardegna (Crustacea, Amphipoda, Gammaridae). Fragm. ent., 11 (1): 73-82.
Shozmaker, C. R., 1959. Three new cave amphipods from the West Indies. J. Wash. Acad. Sci., 49 (8): 273-283.

Stock, J. H., 1980. Regression model evolution as exemplified by the genus Pseudoniphargus (Amphipoda). Bijdr. Dierk., 50 (1): 105-144.

, 1981. Amsterdam Expeditions to the West Indian Islands, Report 14. The taxonomy and zoogeography of the family Bogidiellidae (Crustacea, Amphipoda), with emphasis on the West Indian taxa. Bijdr. Dierk., 51 (2): 345-374. 